\title{
The behavior of Coastal Families Related to the Household Waste Management for the Sustainability of Marine Resources using gender Approach in Kapoposang Islands, South Sulawesi
}

\author{
Etnayanti $^{1}$, Mardiana E.Fachry ${ }^{2}$, Hazairin Zubair ${ }^{3}$ \\ ${ }^{1,3}$ Postgraduate School of Hasanuddin University, Indonesia \\ ${ }^{2}$ Faculty of Marine and Fisheries Sciences, Hasanuddin University, Indonesia
}

Received: 08 Nov 2020; Received in revised form: 15 Dec 2020; Accepted: 25 Dec 2020; Available online: 30 Dec 2020 C2020 The Author(s). Published by Infogain Publication. This is an open access article under the CC BY license (https://creativecommons.org/licenses/by/4.0/).

\begin{abstract}
Kapoposang Islands is one of the many islands in South Sulawesi which has small island development characteristics and a marine tourism park that serves as a marine conservation area and marine tourism site. These main features lead to the many activities performed by the community that may potentially damage the marine ecosystem. This study aims to understand the behavior of coastal families, both men and women through their roles and activities in household waste management that may support the sustainability of marine resources. Samples were determined through random sampling and a total of 18 families from 4 villages was selected. This study used a qualitative approach and descriptive correlational analysis. The results showed that there were two family activities that may potentially produce household waste: (1) domestic activity and (2) economic activity such as fishing and home industry such as fish processing and coconut oil production. The family's knowledge about household waste (38.8\%) and plastic that does not decompose (11.1\%) was low. This affected family behavior where $72.2 \%$ of women disposed their household waste into the sea compared to $30 \%$ of men disposing their fishing waste into the sea. Little support from the village government in household waste management contributed to these behaviors, with only $27.8 \%$ samples ever attended recycling training and there was no final waste disposal available on the islands. The conclusion is that the predominant behavior of coastal families in household waste management remains harmful to the environment because of the low support from the village government in providing training activities and facilitation.
\end{abstract}

Keywords - Behavior, coastal families, household waste, marine resource sustainability.

\section{INTRODUCTION}

Waste and trash is a growing problem in today's world, including in Indonesia. According to the data from the Ministry of Environment and Forestry in ${ }^{1}$ the average waste generated per day in Indonesia is 67.8 tons a day. While South Sulawesi is estimated to generate waste as 1200 tons a day. This number continues to show an increase from year to year, even though the government has issued Law No. 18 of 2008 regarding waste management that needs to be carried out comprehensively and integrated from upstream to downstream ${ }^{2}$. The mentioned regulation is in line with the regional development objectives which try some efforts to optimizing the local resources for the society welfare by taking into account the preservation of environmental functions. Therefore, the local resources have a dual roles as a resource based economy and as a life support system. Hence, the local resources need to managed in a balanced manner to ensure the sustainability of development ${ }^{3}$ 
There are several factors that may influence the increase in waste and trash produced by a country, one of which is human behavior ${ }^{4}$. Behavior is a human act, whether it is over behavior or covert behavior. Behavior can be captured directly through the senses, for example garbage activity and picking up scattered trash. Meanwhile, motivation, attitudes, interests, and feelings cannot be directly captured by the senses.

In coastal communities, the behavior of disposing of garbage at sea is still a bad habit that difficult to change. As a consequence, littering and poor waste management results in marine pollution and poses dangers to marine ecosystems. Marine pollution is also caused by fishing activities that produce diesel fuel and net waste. In addition, the polluted sea is also caused by fishing activities that produce diesel fuel and net waste. However, the role of the family is very important, considering the household waste contributes to a large amount of waste in Indonesia. When it is related to gender roles, the role of women in domestic is very large ${ }^{5}$. Based on this, the study tries to raise the problem of family behavior in coastal communities in waste management and household trash through a gender approach in the Kapoposang Islands, Pangkep Regency, South Sulawesi.

\section{METHODOLOGY}

\subsection{Research Sites}

The research was conducted in Kapoposang Island, Mattiro Ujung Village, Liukang Tupabiring District, Pangkajene Regency, South Sulawesi Province. Kapoposang Island was selected as the research location was carried out with the consideration that Kapoposang Island is one of the islands that has polluted coastal conditions due to waste and household waste.

\subsection{Technique for Determining Samples and Data Sources}

The sample was selected through the Stratified Random Sampling technique as much as $15 \%$ of the total population of 117 families who were in the neighbourhood 1 to 4 (RT I, RT II, RT III and RT IV). The total sample was 18 people. The data consisted of primary data which obtained from interviews and secondary data from the Kapoposang Village office data and various sources related to the research objectives.

\subsection{Research methods and data analysis}

The research was done in qualitative using descriptive correlation analysis ${ }^{6}$, which describe the relationship between family behavior and activities related to waste and trash management along with the government support, Harvad Theory is used to answer the gender roles ${ }^{7}$.

\section{RESULTS AND DISCUSSION}

\subsection{Results}

a. The overview of the Kapoposang Island

Kapoposang Islands is designed as a marine tourism park located in the westernmost part of the Spermonde Archipelago and is more precisely part of the Liukang Tuppabiring District area. In general, the facilities and infrastructure in Kapoposang Island are relatively limited. The only educational facility in the island is an elementary school. The land area is about 42 hectares. The total population of Mattiro Ujung Village is 522 people including 249 men and 273 women. There are 117 head of households. Most of the Kapoposang Island residents are fishermen. Their activities include fishing, collectors, boat builders, and house builders ${ }^{8}$.

\section{b. Respondent Characteristics}

Age and Education background are elements that are closely related to one's behavior in acting which are described as follows:

\section{c. Age}

Age according to ${ }^{9}$ can be described as follows: early adulthood, with ages between 18-29 years, middle adults between 30-50 years old, and old adults with more than 50 years of age. In table 1, the average age of the respondents, both male and female, is mostly classified as early to middle adulthood, namely the ages of 25-45 years, and older adults who are more than 50 years old. The percentage of males in early adulthood to middle adulthood was 9 people $(50.0 \%)$ and 6 women $(33.3 \%)$, and the percentage of older adults over 50 years of age were male respondents - 1 person $(5.6 \%)$ and 2 women $(11.1 \%)$. In early and middle adulthood, the number of male respondents was more than the number of female respondents, and the same was true for the number of elderly adults. shown in table 1.

Table 1. The number and percentage of respondents by age in Kapoposang Island

\begin{tabular}{llll}
\hline No & Age & Total(person) & Percentage (\%) \\
\hline $\mathbf{1}$ & $25-35$ & 6 & 33,3 \\
\hline $\mathbf{2}$ & $36-45$ & 5 & 27,8 \\
\hline $\mathbf{3}$ & $46-55$ & 4 & 22,2 \\
\hline $\mathbf{4}$ & $>55$ & 3 & 16,7 \\
\hline \multicolumn{2}{l}{ Total } & 18 & 100
\end{tabular}

Source: Primary data processed in 2020 


\section{d. Education}

Education has become a necessity to improve the quality of human resources, education in coastal families is still consider low. It is related to knowledge and limitations in accessing education caused by economic factors as well as the distance to schools and locations on the island. As a result, the island community in general experienced a basic education of $77.7 \%$ and higher education of $22.3 \%$. This is shown in table 2.

Table 2. The number and percentage of respondents based on education in Kapoposang Island

\begin{tabular}{|c|c|c|c|}
\hline No & Education & Total (person) & $\begin{array}{c}\text { Percentage } \\
(\%)\end{array}$ \\
\hline \multirow[t]{2}{*}{1} & Not completed in & & \\
\hline & Elementary School & 8 & 44,4 \\
\hline 2 & Elementary School & 6 & 33,3 \\
\hline \multirow[t]{2}{*}{3} & Junior High & & \\
\hline & School & 3 & 16,7 \\
\hline \multirow[t]{2}{*}{4} & $\begin{array}{l}\text { Senior High } \\
\text { School }\end{array}$ & 1 & 5,6 \\
\hline & & 18 & 100 \\
\hline
\end{tabular}

Source: Primary data processed in 2020

This is in accordance with ${ }^{10}$, which states that people who have better human resources, in the sense that a higher level of education, will easily understand the benefits of something.

\subsection{Discussion}

a. Coastal family activities in waste and trash management

Study shows the household activities that potentially generate waste and household trash, which are 1) domestic activities 2) fishing activities 3) Industry activities. All of these activities represents the gender roles, men and women contribution in waste and trash management related to the knowledge and facility availability.

b. Family knowledge about waste and trash

It is necessary to increase society knowledge about waste and trash management to make them aware to protect their clean environment from waste and trash. Knowledge can be obtained through training, socialization from institutions, electronic media such as radio and television as expressed by one respondent:

“... I don't remember..., if there was counseling about waste from the government, maybe in the next village but we never get it here...." (dg. Ma, 35 years old).

The results showed that the less knowledge level of coastal families about waste and trash about $11.1 \%$, including knowledge that plastics are not easily degraded (88.8\%) as shown in Table 3 in the appendix.

Table 3 The number and percentage of family knowledge level in waste and household trash management.

\begin{tabular}{|c|c|c|c|c|c|c|c|c|c|}
\hline \multirow{3}{*}{ Fisherman Family Knowledge } & \multicolumn{3}{|c|}{ Understand } & \multicolumn{3}{|c|}{ Quite Understand } & \multicolumn{3}{|c|}{ Not Understand } \\
\hline & \multicolumn{2}{|c|}{$\begin{array}{c}\text { Total } \\
\text { (person) }\end{array}$} & \multirow[t]{2}{*}{$\begin{array}{c}\text { Percentage } \\
(\%)\end{array}$} & \multicolumn{2}{|c|}{$\begin{array}{c}\text { Total } \\
\text { (person) }\end{array}$} & \multirow[t]{2}{*}{$\begin{array}{c}\text { Percentage } \\
(\%)\end{array}$} & \multicolumn{2}{|c|}{$\begin{array}{c}\text { Total } \\
\text { (persons) }\end{array}$} & \multirow[t]{2}{*}{$\begin{array}{c}\text { Percentage } \\
(\%)\end{array}$} \\
\hline & $\mathrm{L}$ & $\mathrm{P}$ & & $\mathrm{L}$ & $\mathrm{P}$ & & $\mathrm{L}$ & $\mathrm{P}$ & \\
\hline Able to differentiate waste and trash & 0 & 0 & 0,0 & 4 & 3 & 38,8 & 6 & 7 & 61,2 \\
\hline Non-degradable plastic waste & 0 & 2 & 11,1 & 1 & 3 & 22,2 & 5 & 7 & 66,7 \\
\hline Residual ship engine oil can pollute the sea & 2 & 2 & 22,2 & 8 & 6 & 77,7 & 0 & 0 & 0,0 \\
\hline Waste nets can destroy the sea & 0 & 0 & 0,0 & 3 & 2 & 27,7 & 7 & 6 & 72,3 \\
\hline $\begin{array}{l}\text { Throwing waste and rubbish into the sea will } \\
\text { damages the ocean }\end{array}$ & 5 & 5 & 55,6 & 3 & 1 & 22,2 & 2 & 2 & 22,2 \\
\hline Sorting out wet, dry organic and inorganic waste & 0 & 0 & 0,0 & 3 & 6 & 50,0 & 7 & 2 & 50,0 \\
\hline
\end{tabular}

Source: Primary data processed in 2020

\section{c. Domestic activities and waste and trash management}

${ }^{11}$ Suggest that before most women were born, domestic activities had long been attached to women and had become a culture and customs. Women are always in the connotation of human domestic workers (homemakers). They got a negative perception where they were unable to 
contribute actively outside the house so that their role is not just an activity in the home. This can be seen in Kapoposang Island where domestic activities are related to household affairs, cooking, washing, taking care of the house, children and husbands. Domestic activities are roles that are culturally entrusted to women. Therefore women have the potential to produce waste and garbage.

\section{d. Fishing Activity}

In carrying out fishing activities, fishermen have produced waste and trash in the fishing area in the form of plastic waste $(90 \%)$, additional fuel/oil, diesel $(80 \%)$ and fishing gear/ trawling /trawl waste $(70 \%)$. In this case, unfortunately most fisherman throw their waste to the sea, as shown in Table 4.

Table 4. The Number and Percentage of waste types and trash generated in economic activities (fishing)

\begin{tabular}{|c|c|c|c|}
\hline No & $\begin{array}{l}\text { Types of waste and } \\
\text { trash related to } \\
\text { fishing activities }\end{array}$ & $\begin{array}{l}\text { Total } \\
\text { in } \\
\text { person } \\
\text { (orang) }\end{array}$ & $\begin{array}{c}\text { Percentage } \\
(\%)\end{array}$ \\
\hline 1 & $\begin{array}{l}\text { Plastic waste/food } \\
\text { wrappers (eg } \\
\text { noodles packages) }\end{array}$ & 9 & 90,0 \\
\hline 2 & Used supplies trash & 6 & 60,0 \\
\hline 3 & Cigarette butts & 10 & 100 \\
\hline 4 & Toxic waste & 2 & 20,0 \\
\hline 5 & Fishing gear waste & 7 & 70,0 \\
\hline 6 & $\begin{array}{l}\text { Waste fuel (eg oil } \\
\text { and diesel) }\end{array}$ & 8 & 80,0 \\
\hline
\end{tabular}

Source: Primary data processed in 2020

Table 5 Number and percentage of respondent who is littering during the fishery activities

\begin{tabular}{clcc}
\hline No & \multicolumn{1}{c}{$\begin{array}{c}\text { Behaviour while at } \\
\text { sea }\end{array}$} & $\begin{array}{c}\text { Total } \\
\text { (person) }\end{array}$ & Percentage \%) \\
\hline 1 & $\begin{array}{l}\text { Throwing plastic } \\
\text { waste/food wrappers } \\
\text { to the sea }\end{array}$ & 3 & 30,0 \\
2 & $\begin{array}{l}\text { Throwing used } \\
\text { supplies trash to the } \\
\text { sea }\end{array}$ & 2 & 20,0 \\
3 & $\begin{array}{l}\text { Throwing cigarette } \\
\text { butts to the sea }\end{array}$ & 1 & 10,0 \\
4 & $\begin{array}{l}\text { Throwing toxic } \\
\text { waste to the sea }\end{array}$ & 0 & 0,0 \\
5 & Throwing fishing & 2 & 20,0
\end{tabular}

gear to the sea

6 Throwing waste 2

fuel, oil and diesel to

the sea

Total

10

100

To find out the behavior of fishermen when carrying out fishing activities on waste management and waste in the sea is shown in table 5 in the appendix, it is quite high positive behavior of fishermen when fishing, it is seen that only $30 \%$ have ever thrown plastic waste and $20 \%$ disposed of remaining supplies, tool waste catch and waste oil. This is because there is already awareness not to throw garbage and waste in the sea. There are even fishing boats that prepare trash bin, even from diesel drums or plastic bags where food is carried.

Fish production, coconut oil production and raising poultry in the form of chickens and ducks is kind of activities by fishermen's family which handle by women. The production process is still in simple way only sell around the island and for their own family regular consumption. The number of coconut trees in the island is become the reason behind the coconut oil making activities. Another activity of fishermen's wives that has economic value is manage their husband's fish catches result. In fact, some of the husband's work is taken over by women. So there is a balance of jobs for women and men in meeting economic needs. Women's activities in helping their husbands to provide or repair boat equipment such as provision of "pakkaja", $80 \%$ of fishermen's wives carry out these activities in the season of "torani" flying fish eggs, yet this kind of activity poses the increased waste in Kapoposang Island in the last two years, as a consequence, the Kapoposang Island area was experience environmental damage

\section{e. Home industry activities}

Regarding the category of types of business carried out by fishermen's wives in Kapoposang Island can be seen from the aspect of community interaction with the available economic resources in Kapoposang Island, the fishermen's wives of Kapoposang Island fall into two of the three categories of community groups put forward by ${ }^{12}$. where coastal communities can be grouped into three categories as; 1) Direct users of environmental resources, such as fishermen, fish cultivators in coastal waters (using floating nets or cages); 2) Processors of fish or other marine products, such as fish dryers, coconut oil entrepreneurs and so on; 3) Supporting fishery economic activities, such as 
shop owners or boatmen entrepreneurs. Based on these categories, women in Kapoposang Island correspond to points two and three.

The condition of fishermen who do not have large capital is generally only able to meet household consumption needs. It is not uncommon for one month to go to sea without getting paid due to a lack of catch ${ }^{13}$. Fishermen's wives has an important role in supporting family financial by helping their husband. It is known that the fisherman income is relatively low income and uncertainty. Apart from their roles as wives and mothers in domestic activities, fishermen's wives have a productive economic role to help meet household needs ${ }^{14}$. Coastal women have the potential to be empowered in the productive economic sector because they have enough free time and abundant availability of natural resources ${ }^{15}$. In traditional fishermen groups, the role of fishermen's wives is demanded to be greater in looking for other income alternatives to meet household economic needs. The smaller the household income generated by the husband, the greater the role of the wife in contributing income to meet household needs ${ }^{16}$. The results of the Coastal Community Development Project-International Fund for Agricultural Development (CCDP-IFAD) program regarding poverty alleviation in the processing sector by fishermen's wives which contribute to an increase in fishermen household income $^{17}$. This common phenomenon is also happens in Kapoposang Island, as household industrial activities on economic/productive activities on a household scale also affect the waste producers on Kapoposang Island in the form of "biodegradable coconut dregs". However, the number of the piles up in one landfill potentially contribute to marine pollution due to the remaining oil from the coconut dregs. The waste produced during the wave season is the remnants of torn nets and parts of ships that are no longer fit for use that are disposed of at sea which are very dangerous for the sustainability of the marine ecosystem. Nets that are often found in the sea, when it goes down to the seabed it will cover quite a lot of coral reefs on the Kapoposang Island, as a result the coral is covered and causes the coral to die.

f. Gender roles and waste and trash management behavior

According to the data analysis, $11.1 \%$ of respondents who recycled waste and trash. The remaining $90 \%$ did not treat but throw away and burn or stockpile. It was also found that the largest type of waste in Kapoposang Island was plastic. Plastic waste is particularly problematic as a pollutant because it is so long-lasting. Plastic items can take hundreds of years to decompose, therefore it is better to recycle it so that it can be reused. However, it was found ISSN: 2456-1878 that only $11.1 \%$ of women had attended recycling training, by utilising plastic bottles. In terms of gender roles, it is known that men are only involved in activities of lifting trash and piling up garbage $(11.1 \%)$. The rest of the activities related to waste and garbage are done by women. As shown in table 6 in the appendix.

Table 6 Gender role in the related activities to wate and trash in fishermen family in Kapoposang Island.

\begin{tabular}{|c|c|c|c|c|c|c|}
\hline No & $\begin{array}{l}\text { Type of } \\
\text { Activities }\end{array}$ & $\mathrm{L}$ & $\%$ & $\mathrm{P}$ & $\%$ & Notes \\
\hline 1 & $\begin{array}{l}\text { Washing } \\
\text { clothes }\end{array}$ & 3 & 16,6 & 8 & 44,4 & $\begin{array}{l}\text { Three times } \\
\text { a week in } \\
\text { average }\end{array}$ \\
\hline 2 & Cooking & 2 & 11,1 & 8 & 44,4 & $\begin{array}{l}\text { Done } \\
\text { everyday by } \\
\text { women } \\
\text { while men } \\
\text { done it } \\
\text { occasionaly }\end{array}$ \\
\hline 3 & $\begin{array}{l}\text { Going to } \\
\text { the market }\end{array}$ & 3 & 16,6 & 8 & 44,4 & $\begin{array}{l}\text { Weekly } \\
\text { based on } \\
\text { market } \\
\text { schedule. } \\
\text { Fishermen } \\
\text { going to } \\
\text { market to } \\
\text { buy fishing } \\
\text { gear }\end{array}$ \\
\hline 4 & $\begin{array}{l}\text { Throwing } \\
\text { garbage }\end{array}$ & 2 & 11,1 & 8 & 44,4 & Every day \\
\hline 5 & $\begin{array}{l}\text { Burn } \\
\text { garbage }\end{array}$ & 0 & 0,0 & 8 & 44,4 & $\begin{array}{l}\text { According } \\
\text { to the waste } \\
\text { type }\end{array}$ \\
\hline 6 & $\begin{array}{l}\text { Pile up } \\
\text { trash }\end{array}$ & 2 & 11,1 & 8 & 44,4 & Not sure \\
\hline 7 & $\begin{array}{l}\text { Trash } \\
\text { sorting }\end{array}$ & 0 & 0,0 & 8 & 44,4 & Unsorted \\
\hline
\end{tabular}

Source: Primary data processed in 2020

\section{CONCLUSION}

The behavior of coastal families in waste and trash management has not supported the sustainability of marine resources, which is due to the lack of knowledge and support from the government in providing waste disposal facilities and waste recycling training programs. 


\section{REFERENCES}

[1] Hariyanto. (2014). Waste Management in Semarang City Towards a Clean City. Journal of Geography 11 (2) : 237246. Rosnawati W., Bahtiar.,dan Ahmad H. (2007). Management of Household Waste at Above Sea Residential Communities in the District of Ternate City. Techno Journal $6(2)$.

[2] Muta'ali Lutfi. (2012). Environmental Carrying Capacity for Regional Development Planning. Yogyakarta : Publishing Agency of the Faculty of Geography, Gadjah Mada University.

[3] Sarwono, S. W. (2002). Social Psychology: Individual and Social Psychological Theories. Jakarta: PT. Balai Pustaka

[4] J Mansour Faqih. (2010). Gender Analysis and Social Transformation. Yogyakarta: Pustaka Pelajar. Page 7.

[5] Sugiyono. (2016). Quantitative Research Methods, Qualitative and $R \& D$. Bandung: PT Alfabet.

[6] Herien Puspitawati, (2013). Gender Concepts, Theory, and Analysis. Bogor: PT. IPB Press. Page 10

[7] Coremap II. (2007). Profile of Small Islands of Pangkep Regency. Coremap

[8] Mugniesyah SS. (2006). Adult education teaching materials.. Bogor (ID): Department of Communication Science and Community Development.

[9] Notoatmodjo, Soekidjo. (2012). Health Education and Behavior. Jakarta: Rineka Cipta

[10] Tuwu.D. 2018. The Role of Women Workers in Fulfilling the Family Economy from Domestic Roles to the Public Sector. Journal of Research Results 13 (1) : 2541-0717

[11] Kusnadi. (2003). The Roots of Fishermen's Poverty. LkiS. Yogyakarta.

[12] Alpiani, (2019). Relationship Patterns and Punggawa-Sawi Production Sharing Systems on Bagan Rambo Fishing Tools in Barru Regency. Gorontalo Fisheries Journal. P - ISSN : 2614 - 1132 2(1)

[13] Anna, Zuzy. (2012). The Impact of Financial Assistance on Income: The Case of Women Fish Vendors in North Coast of Java. Asian Fisheries Science Special Issue 27S (2014): 211-224.

[14] Fachry, Mardiana E, and Alpiani. 2018. Analysis of Sustainable Economic Empowerment of Coastal Women in South Sulawesi (WID and GAD Concept Approaches to Fishery Product Processing Enterprises). Proceedings of the National Seminar on Marine Socio-Economics, ISBN.978602-0804-51-4: 363-372

[15] Zein, A. (2000). The influence of technological change in income and social structure in artisanal fisheries in Padang, Indonesia. Bung Hatta University. Padang.

[16] Ummung, Andi and Massiseng, Andi Nur Apung. (2019). Empowerment of Women's Groups in Increasing Income through the CCDP-IFAD Program in Bira Village, Tamalanrea District, Makassar City. Proceedings of The National Seminar on Food, Technology, and Entrepreneurship. ISBN: 978-602-51509-2-0: 76-82. 